\title{
Smart Security by Predicting Future Crime with GIS and LBS Technology on Mobile Device
}

\author{
Gaurav Kumar ${ }^{1}$, P. S. Game ${ }^{2}$ \\ ${ }^{1}$ Pune Institute of Computer Technology, Savitribai Phule Pune University, Pune, India \\ ${ }^{2}$ Professor, Pune Institute of Computer Technology, Savitribai Phule Pune University, Pune, India
}

\begin{abstract}
Today's biggest concern is the safety and security of peoples specially women, children and old age persons [4]. Peoples feel unsafe as the crime rate has increased very rapidly. Crime are recorded and investigated on the basis of FIR [2]. This traditional method does not able to predict which type of crime is going to happen in future. As compared 20th century, now Mobile Phone users have increased and services like Location Based Service (LBS) is common now a days. Apart from traditional LBS new technology like GIS i.e. Geographic Information System are used for collecting information of different areas. After collection this data, it is used for analysis and predicting purpose. Decision tree algorithm is used for the classification of criminal data obtain from different state police stations. As the data is classified then frequent crime pattern can be clustered and shown on the user smart phone using GIS [7]. Nowadays security of woman's is at the stake in our country, this application will include Security alert facility for the woman's or the user which is using the app. If the user current location is in the dense crime cluster then his/her location information is send to the nearest police station or near-by friends [8]. System will be implemented using client server architecture where Android phone will act as client and MYSQL database will be used as server.
\end{abstract}

Keywords: GIS, Security, LBS, Crime Classification, Data Mining, Security Alert, Android, MYSQL.

\section{Introduction}

Providing security to citizen of India specially women, children and old age persons are today's major challenge [4]. In past years, amount of crime has become major problem in most of the countries. It has created unsafe environment among peoples. People are migrating different places in order to live a peaceful live. There are different laws which are for ensuring people safety. But criminals have advanced in technology in such a way that they are using new method to threaten people. After looking in past, we found that way of communication has changed and peoples now using smart phone which are powered with services like LBS and GPS. Apart from traditional LBS new technology like GIS i.e. Geographic Information System are used for collecting information of different areas. But still police investigation process follows traditional manual method. In our proposed system crime data set is used as an input for GIS. As the data is available, it is used for analysis and predicting purpose.

Decision tree algorithm is used for the classification of criminal data obtain from different state police stations. As the data is classified then frequent crime pattern can be clustered and shown on the user smart phone using GIS [7].

We can use this concept to provide security to our citizens by just using smart phone and GIS technique. Citizens security is one of the major issue that need to be solved as soon as possible in our country. Proposed system includes Security alert facility for the user who will use this application. If the user current location is in the dense crime cluster then his/her location information is send to the nearest police station or near-by friends [8].

System will be implemented using client server architecture where Android phone will act as client, ArcGIS will be used as run-time environment and MYSQL database will be used as server. Java will be used as a programming language and
PHP as a scripting language. It will also use QGIS opensource software for creating maps of classified crime type and plot crime prone zone over it.

\section{A. Data Source}

Over past year's GIS and LBS had became one of the necessary component in all kinds of business, government agency, cyber crime and criminal activities. As it provide a system for managing all kind of information data according to location.

Collecting data using GPS, GIS and LBS which can be used reveling trends among collected data. It was not possible earlier with the manual data collection method and it was very time consuming. Crime related data are collected from different government websites that provide free crime dataset and also from local police FIR records. GPS is one of the prime sources of data collection method when there is a need for location related data on smart phone.

\section{Literature Survey}

Security is major issue in today's fast growing world. That why there are many researchers had contributed and come up with different solution in order to provide citizens security.

AL-Mazloum, Omer and Abdullah (2014) proposed an android application which uses GPS and SMS technology to track child location and show on parent's mobile map. There are mainly two application one for child and another for parents in which child does not have to perform any task. Child application will be running in background and when ever parent wants his/her child location then it just needs to request to child application and child application will responds with SMS and location is shown on map in real time. 


\section{International Journal of Science and Research (IJSR) \\ ISSN (Online): 2319-7064 \\ Index Copernicus Value (2013): 6.14 | Impact Factor (2014): 5.611}

Nitin and Swati (2014) considered huge data-set of criminal records as an input and J48 Decision tree algorithm had been applied. After applying algorithm different cluster was formed in order to organize data into different classes. As soon as the data is been clustered crime pattern is identified by analysis the data over years.

Mohammed Yousif and omer Naser(2013) discussed various technique like GIS, GPS and LBS which focused on collecting data from the user while moving in the environment and storing into the MYSQL database. After collecting data it use to show on user smart phone using GIS map. This paper also discuss the method how it update data on map according to users location

Abhijeet Tekawade and Ahemad Tutake(2013) had proposed an mobile application which include anti theft functionality which describe the features of locating friends or family members on the basis of mobile location based services. Author has developed such a method in which mobile can be tracked and if it gets lost then it will send the Geocoordinates to nearby friends.

Malathi and Santhosh Baboo(2011) had discussed the modification in different exciting algorithm like MV and Apriori algorithm for the purpose of predicting future crime using data mining technique. This paper also identifies the frequent crime year after year and on the basis of change it will predict the future crime that can occur.

So, in the literature survey table different papers advantage and limitation has been identified and try to overcome in the proposed system.

\begin{tabular}{|c|c|c|c|c|}
\hline Title & Year & $\begin{array}{l}\text { Technology } \\
\text { used }\end{array}$ & Advantage & Limitation \\
\hline $\begin{array}{l}\text { GPS and SMS-Based Child } \\
\text { Tracking System Using } \\
\text { Smart Phone }\end{array}$ & 2014 & $\begin{array}{l}\text { GPS and } \\
\text { SMS }\end{array}$ & $\begin{array}{l}\text { It allows the parent to get } \\
\text { their child's location on a } \\
\text { real time map. Child's } \\
\text { device main responsibility is } \\
\text { to reply the GPS position to } \\
\text { the parent's device upon } \\
\text { request. }\end{array}$ & $\begin{array}{l}\text { Very limited } \\
\text { functionality is } \\
\text { provided like } \\
\text { location only no } \\
\text { risk management } \\
\text { is there if it } \\
\text { occurs. }\end{array}$ \\
\hline $\begin{array}{l}\text { Classification of Criminal } \\
\text { Data Using J48-Decision } \\
\text { Tree }\end{array}$ & 2014 & $\begin{array}{l}\text { Data Mining } \\
\text { and } \\
\text { Classification }\end{array}$ & $\begin{array}{l}\text { It is used to classify crime } \\
\text { dataset into different chister, } \\
\text { organizes into different } \\
\text { classes and identifies the } \\
\text { crime patterns. }\end{array}$ & $\begin{array}{l}\text { Splitting the } \\
\text { training records } \\
\text { recursively and } \\
\text { specifying the } \\
\text { termination } \\
\text { condition is major } \\
\text { challeng e. }\end{array}$ \\
\hline $\begin{array}{l}\text { Development of Integrated } \\
\text { Mbile GPS GIS System }\end{array}$ & 2013 & GIS and GPS & $\begin{array}{l}\text { It is used for collecting data } \\
\text { and showing it on a map } \\
\text { according to the co-ordinates } \\
\text { of the customer location, and } \\
\text { this data can be updated } \\
\text { according to the location of } \\
\text { the customer. }\end{array}$ & $\begin{array}{l}\text { It not being } \\
\text { integrated with } \\
\text { the web GIS } \\
\text { systems for } \\
\text { database access } \\
\text { dynamically such } \\
\text { as ArcGIS server. }\end{array}$ \\
\hline $\begin{array}{l}\text { Mobile Tracking Application } \\
\text { for Locating Friends using } \\
\text { LBS }\end{array}$ & 2013 & $\begin{array}{l}\text { LBS } \\
\text { GPS and }\end{array}$ & $\begin{array}{l}\text { This application includes } \\
\text { anti-theft facility for the } \\
\text { woman's so that information } \\
\text { can be send to the } \\
\text { geographically nearest } \\
\text { police station }\end{array}$ & $\begin{array}{l}\text { It does not use } \\
\text { location from } \\
\text { service provider } \\
\text { and is not } \\
\text { developed as } \\
\text { open source. }\end{array}$ \\
\hline $\begin{array}{l}\text { Location and tracking of } \\
\text { mobile devices: surveillance } \\
\text { stalks the streets }\end{array}$ & 2013 & $\begin{array}{l}\text { LBS and } \\
\text { GPS }\end{array}$ & $\begin{array}{l}\text { Investigates the dimensions } \\
\text { of the problem of people } \\
\text { tracking through the devices } \\
\text { that they carry. }\end{array}$ & $\begin{array}{l}\text { Unable to provide } \\
\text { security and } \\
\text { identity is reviled } \\
\text { easily. }\end{array}$ \\
\hline $\begin{array}{l}\text { An enhanced Algorithm to } \\
\text { Predict a Future Crime using } \\
\text { Data Mining }\end{array}$ & 2011 & $\begin{array}{l}\text { Crime data } \\
\text { mining, MV } \\
\text { Algorithm } \\
\text { and Apriori } \\
\text { Algorithm }\end{array}$ & $\begin{array}{l}\text { It uses existing algorithm } \\
\text { and try to analyze the crime } \\
\text { rate everyyear. On the basis } \\
\text { of changes it predicts the } \\
\text { future crime place, year and } \\
\text { type of crime. }\end{array}$ & $\begin{array}{l}\text { Due to luge } \\
\text { number of crime } \\
\text { dataset it make } \\
\text { complex in order } \\
\text { to find the } \\
\text { relationship and } \\
\text { pattern in the } \\
\text { crime. }\end{array}$ \\
\hline $\begin{array}{l}\text { Mobile geographic } \\
\text { information systems: a Case } \\
\text { study on MANSOURA } \\
\text { UNIVERSITY, EGYPT }\end{array}$ & 2011 & $\begin{array}{l}\text { GIS , LBS } \\
\text { and FBS }\end{array}$ & $\begin{array}{l}\text { It uses WAP technology to } \\
\text { facilitate the communication } \\
\text { and data transfer between } \\
\text { the end user and the GIS }\end{array}$ & $\begin{array}{l}\text { In this the amount } \\
\text { of memory } \\
\text { needed to } \\
\text { visualize a given }\end{array}$ \\
\hline
\end{tabular}

Figure 1: Literature Survey of providing Security through GIS and LBS.
After doing literature survey on GIS, LBS, classification and predicting future crime algorithm, it is found that there is a need for a system which can predict future crime prone area or alert user accordingly. So, in our proposed system we try to develop such system where classification and clustering technology has been used for data-set, GIS for creating maps and android application for showing those maps to users.

\section{Geographic Information Systems}

A. Introduction to geographic information system (GIS) Geographic Information System (GIS) is very important innovative technology which had changed the way of collecting data in different fields. Today it has become the back bone of all survey data collection application from the fields in real time. GIS started since 1964 in Canada for converting an image to a digital image and link it to spatial data or information in the form of list. It mainly works on the creation of several layers like places, soil, rivers, streets, etc.

In 1969 Institute of Research and Environmental Systems founded Environmental System Research Institute (ESRI) in United State by Jack Dingermond which becomes first company that is best known for development of GIS software. In 1970 the first International Conference on GIS has been organized by UNESCO.

There is a very wrong miss conception among peoples between geography and geography information systems. People just think it is new technology of Geography and try to change name such as Spatial Information System or Land Information System. But it differentiates between the traditional information system and new information system specific to places and locations.

So, GIS is comparatively new field, previously it was available to only big companies and university who purchase the software license fees. But today in open source world, software like QGIS is available for free use to everyone who so ever have a laptop or desktop. Due to this open source many GIS application are being developed and made free to use.

\section{A. GIS Definition}

We can define Geographic Information System (GIS) by breaking into 3 sub parts:

1) Geographic: It consists of address, street Intersection, Zip code, pipe, etc.

2) Information: All relational database table, flat file, spreadsheet, digital photo, etc.

3) System: It covers entire management of records, flow control, billing, customer Information System, etc.

\section{B. Representing Data in GIS}

In GIS data is represented are real world which consists of both discrete objects and continuous fields using digital data. When collected data is in different format then it is converted in digital format. Before importing or using data in GIS it needs to specify identities on map as well their relationship. 


\section{International Journal of Science and Research (IJSR) \\ ISSN (Online): 2319-7064}

Index Copernicus Value (2013): 6.14 | Impact Factor (2014): 5.611

Two methods which are used to represent data in GIS are:-

1) Raster Method - In this method data is represented in rows and columns or in cells. Values in each row can be categorized on the basis of different data class they represent.

2) Vector Method - This method consists of different geometries like points, lines, areas, etc, used to represent data. It can be used for representing data that are varying continuously in the environment.

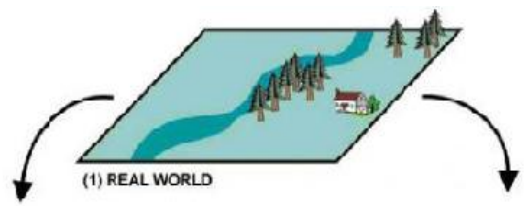

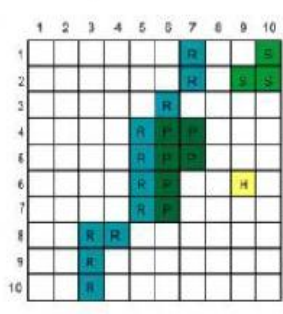

(2) RASTER REPRESENTATION

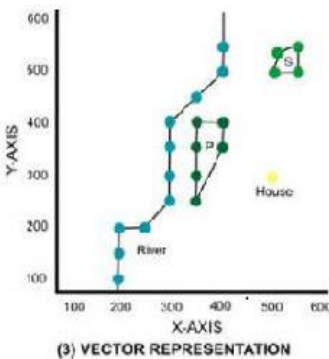

Figure 2: Representing Data in GIS [3]

\section{Mathematical Model}

Input: Indian crime Data-set since 1957 to present.

Output: After classification and clustering crime prone zone is show on map of application installed on user Android phone.

$\mathrm{S}=\mathrm{s}, \mathrm{e}, \mathrm{X}, \mathrm{Y}$,fclassify, fcluster,fmaps,CD,Success,Failue

Where, $\mathrm{S}=\mathrm{A}$ proposed System from programmers viewpoint.

$\mathrm{s}=$ Start State

$\mathrm{e}=$ End State

$\mathrm{X}=$ Input of the System

$\mathrm{Y}=$ Output of the System

fclassify $=$ Classification function of the system.

fcluster $=$ Clustering function of the system.

fmaps $=$ Maps function create different maps as per crime type identified in classification.

$\mathrm{CD}=$ Criminal Data-set of different states of INDIA.

Success $=$ Success state

Failure $=$ Failure State

Now, lets us describe these variables for proposed system

$\mathrm{X}=$ Input of the system

$=$ Indian criminal records of different states.

$=\mathrm{CD} 1, \mathrm{CD} 2, \mathrm{CD} 3, \ldots \mathrm{CDn}$

$\mathrm{Y}=(\mathrm{CM} 1, \mathrm{CM} 2, \ldots \ldots . \mathrm{CMn})$

fclassify $=(\mathrm{c} 1$, cn).

$$
\sum_{i=1}^{n} C i
$$

Where, $n=$ name of crime type classified.

$\mathrm{I}=$ no. of crime type classes will be formed.
Formula used for calculating number of crimes per 100,000 is:-

$\mathrm{CR}=$

$$
\sum_{i=1}^{29}(\text { numberofcrimes /Population }) * 100,000
$$

It gives crime rate per 100,000 of a place.

Assuming threshold for crime prone zone as

$$
\alpha 1=<250, \alpha 2=>250<1000 \text { and } \alpha 3=>1000
$$

fcluster $=(\mathrm{L}, \mathrm{M}, \mathrm{H})$

Where,

$\mathrm{L}=$

$$
\sum_{i=1}^{29} C R<\alpha 1
$$

$\mathbf{M}=$

$$
\sum_{i=1}^{29} \alpha 1<C R<\alpha 3
$$

$\mathrm{H}=$

$$
\sum_{i=1}^{29} C R>\alpha 3
$$

fmaps $=(\mathrm{CM} 1 \ldots \ldots \ldots . \mathrm{CMn})$.

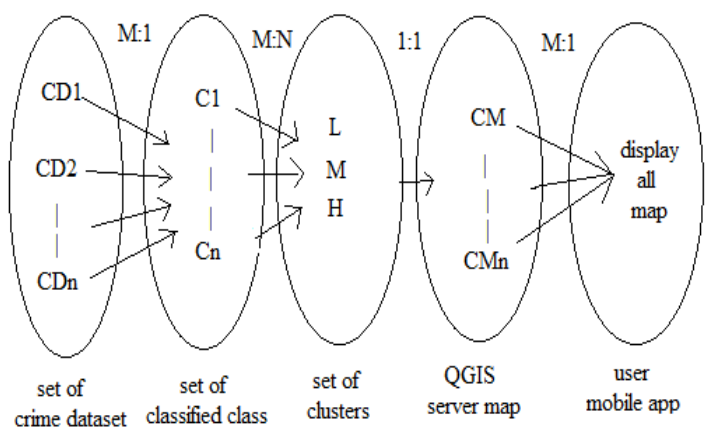

Figure 3: Mapping of different operations in proposed system.

Success State:

1) Classification of data-set is correctly performed using Decision tree algorithm.

2) Clustering of classified data is done into different cluster of high, medium and low crime prone zone.

3) Data is displayed on map using QGIS and Google map of user android phone.

Failure State:

1) Classification is not done correctly.

2) Clustering of data is not performed properly.

3) Data was unable to display on user android phone using QGIS and Google maps. 


\section{Classification of Criminal Data Using Decision Tree Algorithm}

\begin{abstract}
A. Introduction
Now in today's technology world where criminals using latest methods to attack on humanity but despite of that our investigation is still traditional which start with FIR only. Investigation become time consuming and prone to human error due to these methods used everywhere.
\end{abstract}

Large data is collected after FIR and during process of investigation. But classifying those data in proper category in order to extract useful information is very challenging task.

So, in this paper classification of criminal data using Decision Tree Algorithm is been identified. These classification techniques are used to find the common properties in whole criminal records and try to organize them in proper patterns. It uses data mining method which is used for predicting crime patterns and reduces the investigation time to great extent.

\section{B. Data-set Generation}

For generating data for classification process field work like visit to different police stations and visit to different crime data-set provider website is adopted. Advantage of this approach is that the real data can be collected from field work and raw government figures from website which can be merged to get a perfect data-set for testing our classification algorithm. In this scenario Indian data-set of crime is used and also data collected from police station are recorded in rows and columns only.

\section{Classification using Decision Tree Algorithm}

As the data is huge, it needs to be classified on the basis of different types of crime and also the places where the crime occurred. For this reason only decision tree algorithm is used to categorize the data into different section as root, internal and leaf node concepts.

Decision tree algorithm is widely used for classification purpose due to its simplicity.

Structure of this tree is divided into three nodes.

1) A root node which does not have any incoming edge but more outgoing edges.

2) Internal nodes, consists of exactly one incoming edges and two or more outgoing edges.

3) Leaf nodes, have exactly one incoming edges but no outgoing edges.

This algorithm consists of phase like:-

Building the Tree

\section{Building the tree:}

Initially all the training records are at the root. The input to this algorithm consists of crime data-set of India since 1956 to present.

Step 1: Creating Root node $\mathrm{c}=$ crime as a starting point of classification.
Step 2: Check if attribute = murder, riots, robbery etc then classify as crime prone zone class.

Step 3: Else classify as non crime zone area.

Step 4: Repeat step 2, 3 till last record.

Step 5: Terminate tree.

\section{Future Crime Prediction Using Classification and Data Mining}

\section{A. Introduction}

There are lots of attacks being planned and executed but our intelligence are still not able to predict before the attack get executed in real. This is the main reason why loss of life and properties are in huge number.

If there would a system that can able to predict future crime on the basis of past crime record and patterns of conducting crime then we can save lots of innocent life. Like in INDIA Parliament attack, 2001, Taj Hotel Attack, 2006, and 26/11 Mumbai attacks are few major attacks that was unpredictable by intelligence.

If they could have predicted in advance then there would be less or attack could have been stopped. For this there is separate area called as criminology which focus on scientific study of crime, their behaviors and try to identify the relationship among them.

But still there is no such system that can predict the future crime possibility and try to minimize the effect of their in society. One of the reasons is the high Volume of crime datasets and also the complexity of identifying the relationship among those data.

So, in order to overcome those limitations, prediction algorithm is proposed in next section which uses different existing algorithm but with modification which help in providing the desired results.

\section{B. Prediction Algorithm}

The next task after classification is to predict future crime. This involves tracking crime rate changes from one year to the next year and tries to predict for next year on the basis of change patterns identified. For this purpose we need to apply clustering technique to obtain the crime changes as output. Input: crime type, number of cluster, number of Iteration.

Step 1: Randomly choose cluster center.

Step 2: Assign values to clusters based on their distance to the cluster centers.

Step 3: Centers of cluster are adjusted.

Step 4: Go to step 1 until all records over.

Step 5: Output C0, C1, C2, C3 etc.

Where $\mathrm{C} 0=$ higher or dense crime prone cluster. $\mathrm{C} 1=$ less than $\mathrm{C} 0$ and so on till last cluster having minimum crime prone cluster. From the cluster result, the state crime trends for each type of crime are identified for each year.

\section{Proposed System for Security}




\section{International Journal of Science and Research (IJSR) \\ ISSN (Online): 2319-7064}

Index Copernicus Value (2013): 6.14 | Impact Factor (2014): 5.611

After doing classification, clustering and predicting on the basis of criminal records, its time to show them to the user in order to prevent and aware police/users/government. For this purpose android mobile phone is used as a client where application will be installed which consist of GIS map showing predicted data.

User location will be tracked and projected on the map along with the crime predicted areas. If the location of user found in the dense cluster then it will notify with alert message. This system can be the future life saving by preventing attacks to get executed and save much innocent life.

\section{Conclusion}

Crime rate in recent past years had increased very rapidly which includes kidnapping, murder and women sexually assaulted cases. FIR is the first step where crime related information is recorded manually [2]. After this during investigation lots of data are collected and police try to relate those facts to identify crime patterns. This traditional method does not able to predict which type of crime is going to happen in future. In recent years, GIS data collection technique is used for collecting information of different areas like soil information, flood information, tracking vehicle information etc. But there is no system yet proposed which can use GIS for mapping criminal data and advancing traditional police investigation process. In our proposed system crime data-set had been used as an input to the system. Decision tree algorithm is used for the classification of criminal data obtain from different state police stations. As the data is classified then frequent crime pattern can be clustered and shown on the user smart phone using GIS [7].

Safety of our citizens is at risk in our country. Proposed system includes Security alert facility for the application users. So, that his/her location information is send to the nearest friends or family members [8]. It will show GIS data on map of user smart phone.

So, in this way we can able to create a secure environment to some extent. But in order to achieve to the fullest all citizen need to be made aware that we are human and everyone have right to live free without terror.

\section{References}

[1] A. Al-Mazloum, E. Omer, M. F. A. Abdullah, " $G P S$ and SMS-Based Child Tracking System Using Smart Phone", in 2014 International Journal of Electrical, Computer, Energetic, Electronic and Communication Engineering.

[2] Nitin Nandkumar Sakhare, Swati Atul Joshi, "Classification of Criminal Data Using J48-Decision Tree Algorithm", in 2014 International Forum of Researchers Students and Academician.

[3] Nagi Zomrawi Mohammed Yousif, Omer Naser, "Development of Integrated Mobile GPS GIS System", in 2013 International Journal of Engineering and Innovative Technology (IJEIT).

[4] Abhijeet Tekawade, Ahemad Tutake, "Mobile Tracking Application for Locating Friends using LBS", in 2013
International Journal of Innovative Research in Computer and Communication Engineering.

[5] Nitesh Aggarwal, Dr CP Gupta , "Location and tracking of mobile devices: surveillance stalks the streets", in 2013 International Journal of computer law and security Journal.

[6] Malathi. A, S. Santhosh Baboo Reader, "An Enhanced Algorithm to Predict a Future Crime using Data Mining", in 2011 International Journal of Computer Application.

[7] A. Malathi, Dr. S. Santhosh Baboo, "Algorithmic Crime Model Based on the Analysis of Crime Clusters", in 2011 Global Journal of Computer Science and Technology.

[8] Asmaa Ahmed Hussein, Elkhedr Hassan Eibrahim, "Mobile geographic information systems: a Case study on MANSOURA UNIVERSITY, EGYPT', in 2011 International Journal of Computer Science and Information Technology (IJCSIT).

[9] Binod Vaidya, Joel J. P. C. Rodrigues, "mTracker: A Mobile Tracking Application for Pervasive Environment", in 2010 IEEE International Conference on Advanced Information Networking and Applications Workshops. 